Situs Jurnal : $\underline{\text { http://ejournal.stiepancasetia.ac.id/index.php/jieb }}$

Jilid 5 Nomor 2 Juli 2019

Hal $200-209$

\title{
ANALISIS REAKSI PASAR MODAL INDONESIA TERHADAP PERISTIWA PELEDAKAN BOM BUNUH DIRI DI SURABAYA (Studi Kasus pada Perusahaan LQ 45 yang Terdaftar Di Bursa Efek Indonesia)
}

\section{Jumriaty Jusman*}

Abstract: This research is conducted on the basis of observations of events that occur in the country that can prevent security stability. One of the effects of these events is a market reaction. The purpose of this study was to determine whether the capital market reacted to the suicide bombings that occurred in Surabaya, by observing the Abnormal Return behavior obtained by investors and the difference in Avarage Abnormal Return on the Indonesia Stock Exchange (BEI) before and after the bombing. This research was conducted using the event study method with the Market Adjusted Model approach. The sample used is a company whose shares have been listed and included in the calculation of the LQ-45 index. Statistical test of Abnormal Return, Avarage Abnormal Return using paired sample $t$-test. The results of the first hypothesis testing are accepted, because there is a significant abnormal return for investors due to the explosion of Suicide Bombers in Surabaya. While the results of testing the second hypothesis were rejected, because there was no significant difference obtained by investors between Avarage Abnormal Return before and after the suicide bombing in Surabaya

Keywords: Abnormal returns, Event Studies, Bombs in Surabaya, LQ-45, Market Adjusted Models, Market Reactions

Abstrak: Penelitian ini dilukan atas dasar pengamatan terhadap peristiwa-peristiwa yang terjadi di dalam negeri yang dapat menggaggu stabilitas keamanan. Salah satu dampak dari peristiwa (event) tersebut yaitu terjadi reaksi pasar. Tujuan penelitian ini adalah untuk mengetahui apakah pasar modal bereaksi terhadap peristiwa Bom Bunuh diri yang terjadi di Surabaya, dengan mengamati perilaku Abnormal Return yang diperoleh oleh investor serta perbedaan Avarage Abnormal Return di Bursa Efek Indonesia (BEI) sebelum dan sesudah peristiwa Bom tersebut. Penelitian ini dilakukan dengan metode event study dengan pendekatan Market Adjusted Model. Sampel yang digunakan adalah perusahaan yang sahamnya telah tercatat dan masuk dalam perhitungan indeks LQ-45. Uji statistik terhadap Abnormal Return, Avarage Abnormal Return menggunakan Uji t. Hasil pengujian hipotesis pertama diterima, karena terdapat Abnormal Return signifikan bagi investor yang diakibatkan peristiwa peledakan Bom Bunuh Diri di Surabaya. Sedangkan hasil pengujian hipotesis kedua ditolak, karena tidak ada perbedaan signifikan yang diperoleh investor antara Avarage Abnormal Return sebelum dan sesudah peristiwa Bom bunuh diri di Surabaya

Kata kunci : Abnormal return, Event Study, Bom di Surabaya, LQ-45, Market Adjusted Model, Reaksi Pasar

\section{Latar Belakang}

Hampir semua negara di dunia ini memiliki pasar modal, yang bertujuan untuk menciptakan fasilitas bagi keperluan industri dan keseluruhan fasilitas dalam memenuhi 
permintaan dan penawaran modal. Pasar modal dalam suatu negara bisa berperan sebagai sarana perusahaan untuk meningkatkan kebutuhan dana jangka panjang dengan menjual saham atau menerbitkan obligasi (Jogiyanto 2007).

Pasar modal menurut UU No.21 Tahun 2011 adalah kegiatan yang bersangkutan dengan penawaran umum dan perdagangan efek. Perusahaan publik yang berkaitan dengan efek yang diterbitkannya, serta lembaga dan profesi yang berkaitan dengan efek. Sedangkan pengertian pasar modal menurut Widoatmodjo (2012:15) adalah pasar abstrak, dimana yang diperjualbelikan adalah dana-dana jangka panjang, yaitu dan yang keterikatannya dalam investasi lebih dari satu tahun. Kegiatan jual beli dana tersebut dilakukan dalam suatu lembaga resmi yang disebut Bursa Efek.

Faktor-faktor pendukung keberhasilan pasar modal yang mempengaruhi pasar modal seperti dikemukakan (Husnan:2011) sebagai berikut :

1. Supply akan sekuritas

2. Demand akan sekuritas

3. Kondisi sosial dan politik

4. Pertumbuhan ekonomi

5. Aspek hukum dan Peraturan

Dari pejelasan di atas, keberhasilan pasar modal Suatu Negara Ditinjau dari segi stabilitas politik dan keamanan. Kondisi negara yang relatif stabil merupakan faktor yang cukup kondusif bagi kelangsungan investasi baik yang dilakukan oleh swasta dalam negeri maupun asing. Adanya gangguan keamanan dalam negeri akibat peristiwa pemboman dapat mengganggu iklim investasi yang dapat mempengaruhi keputusan investor. Meskipun demikian, harus dianalisa apakah informasi pemboman tersebut relevan bagi investor sehingga mempengaruhi keputusan investasi.

Seringnya Indonesia mendapatkan serangan- serangan terorisme, baik itu berupa pembajakan, penembakan maupun teror Bom. Terorisme di Indonesia dilakukan oleh kelompok militan Jemaah Islamiyah yang berhubungan dengan Al-Qaedah ataupun kelompok militan yang menggunakan ideologi serupa dengan mereka. Sejak tahun 2002, beberapa "target negara Barat" telah diserang. Korban yang jatuh adalah turis Barat dan juga penduduk Indonesia. Terorisme di Indonesia dimulai tahun 2000 dengan terjadinya Bom Bursa Efek Jakarta, diikuti dengan empat serangan besar lainnya, dan yang paling mematikan adalah Bom Bali 2002 (id.wikipedia.org). Johana Indarti (2003) dan Joni Iskandar (2003) dalam hasil penelitiannya menggambarkan bahwa peristiwa Bom Tanggal 12 Oktober 2002 diluar perkiraan atau harapan para investor maupun pasar dan dapat di simpulkan bahwa peristiwa bom bali mengandung informasi serta dianggap sebagai Very bad news, dan juga menunjukkan adanya volume perdagangan yang lebih kecil dari pada sesudah peristiwa bom bali.

Penelitian sebelumnya yang terkait dengan serangan teroris di dalam negeri antara lain Johana Indarti (2003) dan Joni Iskandar (2003) yang menggambarkan peristiwa serangan Bom Bali terjadinya abnormal return negatif yang mempunyai kandungan informasi bagi investor sehingga mengakibatkan pasar bereaksi dengan terjadinya perubahan harga saham dan aktivitas volume perdagangan . Sedangkan, M.Taufiq Hidayat (2012) melakukan penelitian pada peristiwa Bom Jw. Mariott / Ritz Calton 17 Juli 2009, Secara umum menunjukkan bahwa pasar modal Indonesia reaktif hanya pada peristiwa tertentu yang relevan. Peristiwa bom hotel JW Mariott/Ritz Carlton Jakarta adalah peristiwa yang dirasa sudah biasa terjadi sebelumnya. Lebih lanjut, penelitian di Indonesia terkait serangan teroris antara lain dilakukan oleh Cynthia Afriani Utama.dkk (2012). Penelitian tersebut membahas reaksi pasar modal di Indonesia pada sektor Indutri Pariwisata atau Industri lainnya akibat beberapa peristiwa serangan bom teroris dari 
tahun 2000 sampai tahun 2006, yang menunjukkan bahwa secara umum pasar modal Indonesia bereaksi lebih negatif untuk Industri Pariwisata di bandingkan Industri lainnya.

Baru- baru ini Indonesia dikejutkan dengan adanya peristiwa Bom di Surabaya yang diduga peristiwa tersebut adalah serangan terorisme. Dengan adanya peristiwa terorisme tersebut telah mengganggu stabilitas keamanan dan mempengaruhi iklim investasi, khususnya pasar modal Indonesia. Menurut News Data Finansial Tools (KONTAN.CO.ID, Senin 14 mei 2018) Surabaya kembali dilanda aksi bom pagi ini, tepatnya pukul 8.30 waktu setempat. Kondisi ini langsung direspons negatif oleh pasar. Indeks Harga Saham Gabungan (IHSG) turun makin tajam. Senin (14/5) pukul 10.18 WIB, IHSG tergerus 1,45\% ke 5.871,25.

Berdasarkan uraian yang diungkapkan di atas, tujuan penelitian ini adalah untuk mengetahui apakah terjadi reaksi pasar oleh para investor terhadap peristiwa serangan bom bunuh diri di Surabaya setelah Indonesia sering kali mendapatkan serangan teror Bom. Reaksi pasar tersebut diukur dengan menggunakan abnormal return dari harga saham yang diterbitkan pada masing-masing sekuritas yang kemudian variabel tersebut diperbandingkan antara sebelum dan setelah peristiwa pemboman di Surabaya pada tanggal 13-14 Mei 2018.

\section{Kajian Literatur}

Pengertian pasar modal menurut Keputusan Menteri Keuangan RI No.1548/KMK/1990 adalah suatu sistem keuangan yang teroganisasi, termasuk di dalamnya adalah bank-bank komersial dan semua lembaga perantara di bidang keuangan, serta keseluruhan surat-surat berharga yang beredar. Peran pasar modal sangat berpengaruh bagi perekonomian suatu negara karena pasar modal menjalankan dua fungsi sekaligus, yaitu fungsi ekonomi dan fungsi keuangan. Fungsi ekonomi pasar modal yakni berfungsi sebagai lembaga perantara (intermediaries) yang dapat menghubungkan pihak yang membutuhkan dana dengan pihak yang mempunyai kelebihan dana. Sedangkan fungsi keuangan pasar modal adalah memberikan kemungkinan dan kesempatan memperoleh imbalan (return) bagi pemilik dana, sesuai dengan karekteristik investasi yang dipilih.

Dalam pasar modal terdapat pasar perdana dan sekunder. Pasar perdana (primary market) adalah pasar untuk penerbitan baru. Di pasar inilah dana dikumpulkan melalui penjualan arus sekuritas baru dari para pembeli sekuritas tersebut (sektor simpanan) kepada para penerbit sekuritas (sektor investasi). Sedangkan pasar sekunder menurut Brealey, et al, (2008:160) adalah pasar tempat sekuritas yang telah diterbitkan sebelumnya diperdagangkan diantara investor. Dipasar sekunder (secondary market), semua sekuritas yang telah ada dibeli dan dijual. (Horne dan Machowicz, 2007:322).

Studi peristiwa (event study) merupakan studi yang mempelajari reaksi pasar terhadap suatu peristiwa (event) yang informasinya dipublikasikan sebagai suatu peristiwa (Jogiyanto, 2015: 623). Menurut Jogiyanto (2010:4) beberapa tujuan mengapa studi peristiwa banyak digunakan, yaitu untuk menganalisis pengaruh dari suatu peristiwa terhadap nilai perusahaan, mengukur langsung pengaruh peristiwa terhadap harga saham perusahaan terhadap terjadinya peristiwa karena harga saham tersedia pada saat peristiwanya terjadi, dan kemudahan mendapatkan datanya. Apabila pengumuman mengandung informasi (information content), maka diharapkan akan terjadi reaksi oleh pasar pada saat pengumuman tersebut diterima oleh pasar. Reaksi pasar ditandai dengan terjadinya perubahan harga sekuritas yang bersangkutan. Reaksi seperti ini bisa diukur dengan menggunakan return sebagai nilai perubahan harga atau dengan menggunakan abnormal return.

Apabila abnormal return digunakan untuk mengukur reaksi tersebut maka suatu pengumuman yang mempunyai kandungan informasi diperkirakan dapat memberikan abnormal return kepada pasar. Sebaliknya apabila pengumuman tidak mengandung informasi maka dapat dikatakan tidak memberikan abnormal return pada pasar (Jogianto, 
2010:555).Return merupakan hasil imbalan yang diperoleh dari investasi (Jogiyanto,2008). Return dapat berupa return realisasi/ return sesungguhnya / actual return yang sudah terjadi dan return ekspektasi / return yang diharapkan akan terjadi di masa mendatang. Reteurn realisasi dihitung berdasarkan data historis yang berguna sebagai dasar penentuan return ekspektasi dan risiko di masa mendatang. Return ekspektasi adalah return yang diharapkan akan diperoleh investor di masa mendatang.

Efisiensi pasar diuji dengan melihat return tidak normal (abnormal return) yang terjadi. Pasar dikatakan tidak efisien jika satu atau beberapa pelaku pasar dapat menikmati return tidak normal dalam jangka waktu yang cukup lama (Jogiyanto,2010:415).Abnormal return adalah selisih antara tingkat keuntungan sebenarnya dengan tingkat keuntungan yang diharapkan (Husnan,2009:269). Apabila return yang didapatkan lebih besar dari return yang diharapkan berarti ubnormal return positif, hal ini yang diharapkan investor. Begitupun sebaliknya, apabila return yang didapatkan (return realisasi) lebih kecil dari return yang diharapkan (return ekspektasi) berarti ubnormal return akan negatif.

Pengeboman Surabaya 2018 adalah rangkaian peristiwa meledaknya bom di berbagai tempat di Surabaya dan Sidoarjo, Jawa Timur pada 13-14 Mei 2018. Kejadian pertama bom bunuh diri pada hari minggu 13 Mei 2018 yang meledak di Gereja Katolik Santa Maria Jalan Ngagel Madya Utara terjadi pukul 06.30 WIB. Kejadian kedua terjadi di Gereja Kristen Indonesia (GKI) Jalan Diponegoro, sekitar pukul 07.15 WIB. Kemudian terjadi di Gereja Pantekosta Pusat Surabaya (GPPS) Jalan Arjuno terjadi pukul 07.53 WIB. Pada malam di hari yang sama pada pukul 20:00 WIB, terjadi ledakan di sebuah Rumah Susun Sederhana Sewa (Rusunawa) Wonocolo, kawasan Sepanjang, Sidoarjo, Jawa Timur. Ledakan tersebut terjadi pada Blok B di lantai 5 dan terdengar hingga lima kali dan dikonfirmasi merupakan sebuah ledakan bom rakitan yang dibuat oleh penghuni rusunawa. Keesokan harinya pada Senin, 14 Mei 2018 pukul 08:50 WIB, sebuah ledakan terdengar di depan Polrestabes Surabaya. Berdasarkan rekaman CCTV, ledakan terjadi di pintu gerbang Polrestabes Surabaya. Ledakan berasal dari sepeda motor bernomor polisi L 6629 NN dan L 3559 G. Kejadian tersebut korban tewas 28 orang (termasuk pelaku) dan korban luka 57 orang (id.wikipedia.org).

\section{Metode Penelitian}

Penelitian ini menggunakan metode studi peristiwa (event study) yang berfokus pada pengujian reaksi pasar dan menemukan respon investor terhadap suatu peristiwa atau kejadian tertentu. Peristiwa (event) yang diteliti dalam penelitian ini adalah peristiwa non ekonomi yaitu, serangan Bom bunuh diri di Surabaya dan Sidoarjo pada tanggal 13-14 Mei 2018.

Dalam penelitian ini periode pengamatan yang dipergunakan yaitu selama 13 hari bursa terdiri dari: 6 hari bursa sebelum tanggal peristiwa ,1 hari kejadian (event date), dan 6 hari bursa setelah tanggal peristiwa.

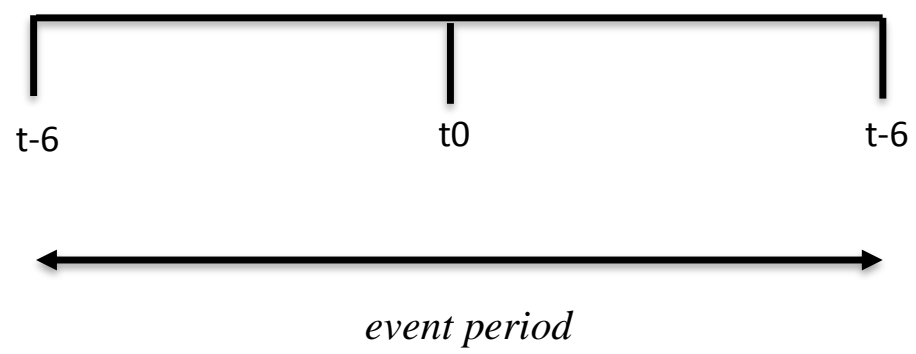

Gambar 1 : Event Windows 
Jenis data yang digunakan penelitian ini adalah data sekunder yang bersumber dari Bursa Efek Indonesia (BEI), yahoo finance serta data publikasi lain yang memuat informasi yang relevan dengan penelitian ini. Data tersebut dapat langsung diakses melalui website resmi Bursa Efek Indonesia (BEI) yaitu www.idx.co.id dan https://finance.yahoo.com/. Adapun data sekunder tersebut adalah sebagai berikut:

1. Harga adjusted close saham harian LQ45 selama periode peristiwa.

2. Adjusted Close harian Indeks LQ45 selama periode peristiwa.

3. Populasi yang digunakan dalam penelitian ini adalah LQ45.

Populasi dalam penelitian ini adalah semua perusahaan yang tercatat sebagai perusahaan go publik di Bursa Efek Indonesia per 12 September 2017 berjumlah 555 perusahaan. Sampel yang digunakan adalah perusahaan yang sahamnya telah tercatat dan masuk dalam perhitungan indeks LQ45 periode Februari sampai dengan Juli 2018.

Teknik pengambilan sampel dilakukan dengan metode purposive sampling yaitu untuk mendapatkan sampel yang dapat mewakili seluruh populasi berdasarkan kriteria-kriteria tertentu. Kriteria pemilihan sampel itu adalah sesuai dengan kriteria saham yang termasuk dalam saham LQ-45. Adapun kriteria saham yang termasuk dalam LQ-45 sebagai berikut :

1. Telah tercatat di BEI minimal 3 bulan.

2. Aktivitas transaksi di pasar reguler yaitu nilai, volume dan frekuensi transaksi.

3. Jumlah hari perdagangan di pasar reguler.

4. Kapitalisasi pasar pada periode waktu tertentu.

5. Selain mempertimbangkan kriteria likuiditas dan kapitalisasi pasar tersebut di atas akan dilihat juga keadaan keuangan dan prospek pertumbuhan perusahaan tersebut

Teknik pengujian menggunakan metode event study yang menganlisis rekasi pasar terhadap informasi melalui parameter abnormal return yang diterima para investor dengan langkah-langkah sebagai berikut :

1. Uji normalitas data

Uji normalitas terlebih dahulu dilakukan sebelum melakukan uji hipotesis penelitian. Pengujian normalitas ini dilakukan untuk mengetahui alat uji statistik apa yang tepat digunakan untuk data, apakah menggunakan alat uji statistik parametrik ataukah non parametrik.

2. Menghitung return sesungguhnya tiap-tiap saham, dengan langkah-langkah sebagai berikut:

$$
R_{i . t}=\frac{P_{\mathrm{i} . \mathrm{t}}-P_{\mathrm{i.t}-1}}{P_{\mathrm{i} . \mathrm{t}-1}}
$$

Dimana :

Rit = return sesungguhnya saham i hari ke-t

Pit = harga penutupan saham i hari ke-t

Pit-t = harga penutupan saham i hari ke-t-1

3. Menghitung Return Ekspektasi

$$
\mathrm{R}_{\mathrm{mt}}=\operatorname{In} \frac{L Q-45 t}{L Q-45 t-1}
$$

Dimana :

Rmt $=$ return pasar periode $\mathrm{t}$

LQ-45t = indeks LQ-45 harian untuk periode $\mathrm{t}$ 
LQ-45t-1 = indeks LQ-45 harian untuk periode $\mathrm{t}-1$

4. Menghitung abnormal return dengan rumus sebagai berikut :

$\mathrm{RTN}_{\mathrm{i} . \mathrm{t}}=\mathrm{R}_{\mathrm{i} . \mathrm{t}}-\mathrm{E}\left[\mathrm{R}_{\mathrm{i} . \mathrm{t}}\right]$

Dimana :

RTNit = return tidak normal saham i pada hari ke-t

Rit = return sesungguhnya untuk saham i pada hari ke-t

$\mathrm{E}$ (Rit) = return ekspektasian untuk saham i pada hari ke- $\mathrm{t}$

5. Menghitung Average Abnormal return (AAR), dengan rumus sebagai berikut:

$A A R_{i t}=\Sigma_{\mathrm{t}}=1 \mathrm{n} A R_{\mathrm{it}}$

Dimana :

AARit : Rata-rata Abnormal return saham pada periode ke-t.

ARit : Abnormal return saham i pada periode ke-t.

$n$ : Jumlah observasi atau jumlah periode.

6. Melakukan Pengujian $\left(\mathrm{H}_{1}\right)$ Signifikansi Abnormal Return di Periode Peristiwa. Data dianalisis dengan menggunakan Uji One Sample t-test.

7. Menguji perbedaan Abnormal Return Mean $\left(\mathrm{H}_{2}\right)$ seluruh saham yang dijadikan sampel lima hari sebelum dan lima hari sesudah peristiwa dengan menggunakan Uji Paired Sample Ttest.

\section{Hasil Penelitian dan Pembahasan}

Hasil pengujian normalitas residual data dengan menggunakan One Simple Kolmogorov Smirnov Test disajikan pada tabel 1.

Tabel 1. Uji Normalitas

\begin{tabular}{lcccccc}
\hline & \multicolumn{3}{c}{ Kolmogorov-Smirnov $^{\mathrm{a}}$} & \multicolumn{3}{c}{ Shapiro-Wilk } \\
\cline { 2 - 7 } & Statistic & $\mathrm{df}$ & Sig. & Statistic & df & Sig. \\
\hline sebelum &, 235 & 6 &, $200^{*}$ &, 889 & 6 &, 312 \\
\hline setelah &, 269 & 6 &, 199 &, 841 & 6 &, 133 \\
\hline \multicolumn{2}{l}{ sumber: Data sekunder yang diolah } & menggunakan SPSS,2018 & & \\
\hline
\end{tabular}

Berdasarkan hasil Uji Normalitas di atas, diperoleh hasil nilai asyimpitonic significance lebih besar dari 5\% ( $\mathrm{p}>0,05)$ pada variable ubnormal return. Dari uji normalitas diatas dapat disimpulkan bahwa analisis data selanjutnya memenuhi syarat untuk menggunakan alat uji parametric t-test, yaitu One Simple t-test dan Paried Sample t-test.

Uji hipotesis pertama $(\mathrm{H} 1)$ digunakan untuk mendeskripsikan ada tidaknya abnormal return saham yang signifikan bagi investor akibat peritiwa Bom Surabaya. Terlebih dahulu dilakukan perhitungan rata-rata abnormal return saham dari seluruh objek penelitian. Kemudian diuji dengan alat SPSS dengan menggunakan uji One Sample t-test dengan tingkat signifikansi 0,05 seperti ditunjukkan pada Tabel 2 . 


\section{Tabel 2. Uji One-Sample Test}

\begin{tabular}{|c|c|c|c|c|c|c|}
\hline & \multicolumn{6}{|c|}{ Test Value $=0$} \\
\hline & \multirow[t]{2}{*}{$\mathrm{t}$} & \multirow[t]{2}{*}{$\mathrm{df}$} & \multirow[t]{2}{*}{$\begin{array}{l}\text { Sig. }(2- \\
\text { tailed })\end{array}$} & \multirow[t]{2}{*}{$\begin{array}{c}\text { Mean } \\
\text { Difference }\end{array}$} & \multicolumn{2}{|c|}{$\begin{array}{l}95 \% \text { Confidence Interval of } \\
\text { the Difference }\end{array}$} \\
\hline & & & & & Lower & Upper \\
\hline t0 & $-1,628$ & 44 &, 111 &,- 0060139 &,- 013461 &, 001433 \\
\hline$t+1$ & 3,488 & 44 & ,001 & 0159192 &, 006720 & ,025118 \\
\hline$t+2$ &, 124 & 44 & ,902 &, 0004351 &,- 006622 &, 007493 \\
\hline$t+3$ & 2,698 & 44 & ,010 &, 0162267 &, 004107 &, 028346 \\
\hline$t+4$ &, 184 & 44 &, 855 &, 0006214 &,- 006193 &, 007436 \\
\hline$t+5$ & 2,105 & 44 &, 041 & ,0077287 & ,000329 & ,015128 \\
\hline$t+6$ &,- 507 & 44 & ,614 &,- 0017497 &,- 008698 & ,005199 \\
\hline
\end{tabular}

Berdasarkan perhitungan statistik pada tabel 2 di atas Average abnormal return yang signifikan di bawah $5 \%(\mathrm{p}<0,05)$ terlihat bahwa terdapat tiga hari bursa yaitu $\mathrm{t}+1, \mathrm{t}+3$ dan $\mathrm{t}+5$ yang signifikan menghasilkan Abnormal Return positif . Selain hari tersebut tidak ada abnormal return signifikan. Hal tersebut berarti mencerminkan terjadinya reaksi pasar sehingga terindikasi bahwa investor selaku pasar merespon secara positif. Hal ini diduga bahwa Investor yang kepemilikan sahamnya di Perusahaan yang memiliki fundamental yang baik tidak akan mudah terpengaruh dengan isu-isu yang berada diluar perusahaan. Sedangkan pada hari peristiwa (t0) menunjukkan tidak terjadinya abnormal return signifikan bagi investor. Hal tersebut diduga kemungkinan besar masyarakat ataupun investor di Indonesia sudah beberapa kali menghadapi peristiwa Bom seperti ini dan sudah kebal terhadap informasi yang berkaitan dengan peristiwa terorisme. Masyarakat maupun Investor juga memberikan kepercayaan kepada Pemerintah dan POLRI mampu menangani situasi dengan cepat ,mengungkap dan menangkap pelaku serta memberantas seluruh terorisme di Indonesia.

Menurut Jogiyanto (2010), Pasar dikatakan tidak efisien jika satu atau beberapa pelaku pasar dapat menikmati return tidak normal dalam jangka waktu yang cukup lama (Jogiyanto,2010:415). Jika dilihat pada $(t+1)$ terjadinya abnormal return signifikan positif , kemuadian keesokan harinya $(\mathrm{t}+2)$ tidak terjadi abnormal return signifikan, hal ini menggambarkan bahwa investor menyerap abnormal return dengan cepat, berarti dalam hal pasar dikatakan efisien.

Berdasarkan penjelasan di atas dapat disimpulka bahwa Ha1 diterima, karena berdasarkan tingkat signifikansi dari hasil pengujian tersebut terdapat abnormal return signifikan bagi investor yang diakibatkan peristiwa peledakan bom di Surabaya. Penelitian ini mendukung penelitian yang dilakukan M.Taufiq Hidayat (2012) bahwa Peristiwa bom di hotel JW Mariott / Ritz Carlton Jakarta Terdapat reaksi berupa terjadinya abnormal return positif pada hari ke-1 sesudah event yaitu sebesar 0,012457 dengan tingkat signifikansi 0.024 namun demikian dalam beberapa hari sudah kembali normal. Oleh karena itu pengujian hipotesis 1 berhasil menolak $\mathrm{H} 0$ dan menerima H1. Namun penelitian ini bertentangan dengan penelitian yang dilakukan Melitina Tecualu dan Rianny Megge (2010) bahwa Hasil penelitian yang menggunakan pendekatan even study ini menemukan bukti empiris bahwa peristiwa Bom Kuningan tanggal 17 Juli 2009 tidak menghasilkan abnormal return yang signifikan bagi investor.

Hipotesis kedua $(\mathrm{H} 2)$ ingin menguji terdapat perbedaan abnormal return yang signifikan sebelum dan sesudah tanggal peristiwa Bom Surabaya . Untuk melakukan pengujian terhadap hipotesis kedua $(\mathrm{H} 2)$ dilakukan dengan membandingkan average abnormal return 6 hari 
sebelum peristiwa bom dengan 6 hari sesudah peristiwa bom. Untuk melihat signifikansi perbedaan AAR sebelum dan sesudah peristiwa dilakukan dengan alat SPSS menggunakan uji beda paired samples t-test yang ditampilkan pada tabel 3 .

Tabel 3. Uji Paired Samples Test

\begin{tabular}{|c|c|c|c|c|c|c|c|c|c|}
\hline & & \multicolumn{5}{|c|}{ Paired Differences } & \multirow[t]{2}{*}{$\mathrm{t}$} & \multirow[t]{3}{*}{ df } & \multirow{3}{*}{$\begin{array}{l}\text { Sig. (2- } \\
\text { tailed) }\end{array}$} \\
\hline & & \multirow[t]{2}{*}{ Mean } & \multirow[t]{2}{*}{$\begin{array}{c}\text { Std. } \\
\text { Deviation }\end{array}$} & \multirow[t]{2}{*}{$\begin{array}{l}\text { Std. Error } \\
\text { Mean }\end{array}$} & \multicolumn{2}{|c|}{$\begin{array}{l}\text { 95\% Confidence Interval of } \\
\text { the Difference }\end{array}$} & & & \\
\hline & & & & & Lower & Upper & & & \\
\hline $\begin{array}{l}\text { Pair } \\
1\end{array}$ & $\begin{array}{l}\text { sebelum } \\
\text { - setelah }\end{array}$ &,- 0096279 & ,0120993 & 0049395 &,- 0223253 & 0030695 & $-1,949$ & 5 & , 109 \\
\hline
\end{tabular}

Berdasarkan hasil pengujian paired sample t-test di atas menunjukkan bahwa rata-rata abnormal return sebelum dan sesudah peristiwa Bom Surabaya sebesar -0,0096279 dengan tingkat signifikansi sebesar 0,109. Hal ini menunjukkan nilai signifikansi lebih besar dari tingkat signifikansi yang telah ditetapkan yaitu $0,05(0,109>0,05)$. Dengan demikian dapat disimpulkan bahwa $\mathrm{H} 2$ ditolak karena tidak ada perbedaan signifikan yang diperoleh investor antara abnormal Return sebelum dan sesudah peristiwa bom Surabaya. Hal tersebut disebabkan karena Indonesia sudah beberapa kali menghadapi peristiwa bom maka investor sudah berpengalaman atas peristiwa tersebut sehingga secara umum pasar bereaksi netral terhadap adanya peristiwa bom di Surabaya.

Penelitian ini mempunyai kesamaan hasil dengan penelitian yang dilakukan oleh Oka Sastian Yudhanagara (2010) bahwa diperoleh hasil abnormal return mean 5 hari sebelum peristiwa adalah sebesar -0.001348 dengan deviasi standar sebesar 0.001452 , sedangakn abnormal return mean 5 hari sesudah peristiwa adalah sebesar 0.002762 dengan standar deviasi 0.006398 dan probabilitas yang dihasilkan sebesar 0,252 pada tingkat signifikasi $5 \%$. Berdasarkan penjelasan tersebut dapat disimpulkan bahwa Ha2 ditolak, karena tidak ada perbedaan yang signifikan antara abnormal return mean sebelum dan sesudah peristiwa. Namun penelitian ini bertentangan dengan Gunawan (2001) yang melakukan penelitian terhadap peledakan bom di halaman parkir gedung BEJ pada tanggal 13 September 2000, bukti empiris menunjukkan bahwa berdasarkan uji beda, peneliti menemukan perbedaan yang signifikan antara rata-rata abnormal return sebelum dan sesudah tanggal peristiwa.

\section{Kesimpulan}

Berdasar hasil analisis data dan pengujian hipotesis yang telah dipaparkan pada bab sebelumnya, dapat dikemukakan beberapa kesimpulan sebagai berikut:

1. Akibat peristiwa Bom Bunuh Diri di Surabaya tanggal 13-14 Mei 2018 memberikan abnormal return positif bagi investor yaitu pada $t+1, t+3$, dan $t+5$, yang berarti terjadi reaksi pasar dan merupakan good news bagi investor. Pada peristiwa /Event Date (t0) tidak terdapat abnormal return yang signifikan yang mencerminkan tidak ada reaksi pasar.

2. Analisis abnormal return 6 hari sebelum dan 6 hari sesudah peristiwa menunjukkan bahwa secara statistik tidak ada perbedaan yang signifikan antara abnormal return 6 hari sebelum peristiwa dengan abnormal return 6 hari sesudah peristiwa. Artinya secara keseluruhan peristiwa Bom Surabaya tidak membawa dampak signifikan pada perubahan return investor selama periode pengamatan. 
Mengingat adanya keterbatasan waktu maupun sumber daya dari peneliti, untuk menyempurnakan penelitian ini, maka penelitian mendatang perlu memperhatikan beberapa hal berikut ini:

1. Dalam penelitian ini, indeks yang digunakan adalah indeks LQ 45. Hasil penelitian akan lebih akurat jika penelitian berikutnya menggunakan Indeks Harga Saham Gabungan (IHSG).

2. Penelitian ini belum mempertimbangkan pergerakan volume perdagangan sahamnya dan faktor eksternal lain yang dapat berpengaruh.

3. Menggunakan metode mean adjusted model atau market model dalam perhitungan abnormal return.

4. Perlu ditambahkan sampel penelitian yang tidak hanya terbatas pada perusahaan LQ-45. Dan Waktu event sebelum dan sesudahnya bisa ditambahkan lebih lama dengan tujuan adanya kemungkinan dampak informasi lain yang berpengaruh terhadap event study tersebut.

\section{DAFTAR PUSTAKA}

Afriani, C. U., dan Lina Hapsari. 2012. Jenis Industri, Kepemilikan Saham Asing dan Reaksi Pasar Modal Akibat Serangan Bom Teroris. Jurnal Akuntansi dan Keuangan Indonesia, $9(2)$.

Ananto, Dedy (2014). Pengaruh Pemilu Legislatif Terhadap Abnormal Return Dan Trading Volume Activity Saham Di Jakarta Islamic Index (Studi Kasus Pada Peristiwa Pemilu Legislatif 09 April 2014). Tesis. Fakultas Syari'ah dan Hukum. UIN Sunan Kalijaga.

Brealey, Myers, Marcus. 2008. Pasar-Pasar Manajemen Keuangan. Edisi 5. Jilid 1 . Jakarta : Erlangga.

Handadari, Cahyaning, 2003. Reaksi Harga Saham di Bursa efek Jakarta terhadap Peledakan Bom di Bali tanggal 12 Oktober 2002. Tesis Mahasiswa Program Pasca Sarjana Magister Manajemen Universitas Sebelas Maret Surakarta. Tidak Dipublikasikan.

Hartono, Jogiyanto. 2007. Teori Portofolio dan Analisis Investasi. BPFE: Yogyakarta.

Hartono, Jogiyanto. 2008. Teori portofolio dan Analisis Investasi. Yogyakarta: BPFE.

Hartono, Jogiyanto. 2010. Metodologi Penelitian Bisnis. Edisi Pertama, BPFE. Yogyakarta.

Hartono, Jogiyanto. 2015, Teori Portofolio dan Analisis Investasi Edisi Kelima. Jakarta: Rajawali Pers.

Herlianto, D. 2002, Reaksi Pasar Modal Indonesiaterhadap Serangan Teroris di AmerikaSerikat (Kasus 11 September di World TradeCenter New York, AS). Buletin Ekonomi.UPN Veteran Yogyakarta.

Hidayat, M, T. 2012. Analisis Reaksi Pasar Modal Indonesia Terhadap Peristiwa Non Ekonomi (Studi Kasus Peristiwa Bom JW Mariott / Ritz Carlton 17 JULI 2009). Media Ekonomi \& Teknologi Informasi Vol.20 No. 2 September 2012 : 16 -32.

Horne, Van dan Wachowicz. 2007. Fundamentals of Financial Management, Prinsip-Prinsip Manajemen Keuangan. Jakarta : Salemba Empat.

Husnan, Suad. 2009. Teori Portofolio dan Analisis Sekuritas. UPP STIM YKPN. Yogyakarta Ikatan Akuntansi Indonesia. 2009. Standart Akuntansi Keuangan; PSAK No.22. Jakarta: Salemba Empat

Indarti, Johana (2003),"Analisis Perilaku Return dan Aktivitas Volume perdagangan Saham di Bursa efek Jakarta (Event Study: Dampak Peristiwa Bom Bali tanggal 12 Oktober 2002 pada Saham LQ 45), Tesis S2 Program Studi Magister Akuntasi Pasca Sarjana Universitas Dipenogoro, Semarang.

Iskandar, Joni (2003), "Reaksi Pasar Modal Indonesia terhadap Peristiwa Peledakan Bom di Legian Bali (Studi Kasus Saham LQ 45 di Bursa Efek Jakarta)", Tesis S-2 Program Studi Magister Akuntasi Pasca Sarjana Universitas Dipenogoro, Semarang. 
MacKinlay, A. Craig, 1997. Event Studies in Economics and Finance. Journal of Economic Literature, Vol. XXXV. Edisi: Maret Hal: 13-19.

Poerwandono,A . 2004. Analisis Reaksi Pasar terhadap Peristiwa Pemboman Bali 12 Oktober 2002 dan Hotel Jw Marriott 5 Agustus 2003. Skripsi. Universitas Sanata Dharma. Yogyakarta.

Rahayu, Wahyu Estining, 2007, Reaksi Pasar Modal Terhadap Pengumuman Perombakan (Reshuffle) Terbatas Kabinet Indonesia Bersatu, Jurnal Bisnis dan Manajemen, Vol. 9 No. 2, Halaman 129-142, Fakultas Ekonomi Universitas Sanata Dharma Yogyakarta.

Rahmawati dan Pandansari, 2016. Reaksi Pasar Modal dari Dampak Peristiwa Bom Plaza Sarinah Terhadap Abnormal Return Perusahaan LQ 45 Yang Terdaftar di Bei. Jurnal Riset Akuntansi dan Keuangan Indonesia, 1(2), 2016.

Rianti, Setyawasih. 2007, "Studi Tentang Peristiwa (Event Study): Suatu Panduan Riset Manajemen Keuangan di Pasar Modal”, Jurnal Optimal, Vol. 1 No. 1, Maret 2007, Hal 52-58.

Sawidji Widoatmodjo. 2012. Cara Cepat Memulai Investasi Saham Panduan Bagi Pemula. Jakarta: PT Elex Media Komputindo

Sunariyah, 2000. Pengantar Pengetahuan Pasar Modal. UPP AMP YKPN. Yogyakarta

Tecualu dan Megge. 2010. Reaksi Pasar Modal Indonesia Terhadap Peristiwa Bom Kuningan Tahun 2009. Jurnal Ilmiah Manajemen Bisnis, Vol.10, No.1, Januari 2010 : 19-30.

Yudhanagara, O.S. 2010. Dampak Peristiwa Peledakan Bom Jw Marriott dan Ritz-Carlton Tanggal 17 Juli 2009 pada Harga Saham di Bursa Efek Indonesia (Studi Kasus Pada Perusahaan LQ 45 yang Terdaftar di Bursa Efek Indonesia). Skripsi. Universitas Sebelas Maret Surakarta. Surakart

www.investasidana.com, diakses pada tanggal 3 Juni 2018.

https://finance.yahoo.com/, diakses pada tanggal 2 Juni 2018.

http://www.idx.co.id , diakses pada tanggal 3 Juni 2018. 